The Folk 



\section{The Folk}

Music, Modernity, and

the Political Imagination

\section{Ross Cole}

무

UNIVERSITY OF CALIFORNIA PRESS 
University of California Press

Oakland, California

(C) 202 I by Ross Cole

Library of Congress Cataloging-in-Publication Data

Names: Cole, Ross, author.

Title: The folk : music, modernity, and the political imagination / Ross Cole.

Description: Oakland, California : University of California Press, [202I] I Includes bibliographical references and index.

Identifiers: LCCN 2021005203 (print) | LCCN 2021005204 (ebook) | ISBN 9780520383739 (cloth) I ISBN 9780520383746 (paperback) | ISBN 9780520383753 (epub)

Subjects: LCSH: Folk Music_-Political aspects-History-I9th century. | Folk Music_-Political aspects-History-2oth century. I Folk songs-Political aspects-History-I9th century. I Folk songsPolitical aspects-History-20th century.

Classification: LCC ML39I8.F65 C65 202I (print) I LCC ML39I8.F65 (ebook) I DDC 306.4/8422-dc23

LC record available at https://lccn.loc.gov/202 I005203

LC ebook record available at https://lccn.loc.gov/2021005204

Manufactured in the United States of America

$\begin{array}{llllllllll}30 & 29 & 28 & 27 & 26 & 25 & 24 & 23 & 22 & 21\end{array}$

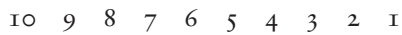


To my family, past and future

Your reason and your passion are the rudder and the sails of your seafaring soul.

-KAHLIL GIBRAN, The Prophet 
